$\begin{array}{ll} & \text { Etnográfica } \\ \text { etnográfica } & \text { Revista do Centro em Rede de Investigação em }\end{array}$

Antropologia

vol. $23(3) \mid 2019$

Vol. 23 (3)

\title{
Uma vida que não se conta: nos caminhos da singularidade
}

A life not to be told: in the paths of singularity

Irlys Alencar F. Barreira e Glória Diógenes

\section{(2) OpenEdition}

Journals

Edição electrónica

URL: https://journals.openedition.org/etnografica/7340

DOI: 10.4000/etnografica.7340

ISSN: 2182-2891

\section{Editora}

Centro em Rede de Investigação em Antropologia

\section{Edição impressa}

Data de publição: 1 outubro 2019

Paginação: 649-672

ISSN: 0873-6561

\section{Refêrencia eletrónica}

Irlys Alencar F. Barreira e Glória Diógenes, «Uma vida que não se conta: nos caminhos da singularidade», Etnográfica [Online], vol. 23 (3) | 2019, posto online no dia 28 novembro 2019, consultado o 20 janeiro 2022. URL: http://journals.openedition.org/etnografica/7340 ; DOI: https:// doi.org/10.4000/etnografica.7340

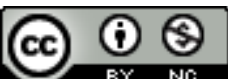

Etnográfica is licensed under a Creative Commons Attribution-NonCommercial 4.0 International License. 


\section{Uma vida que não se conta: nos caminhos da singularidade}

\section{Irlys Alencar F. Barreira e Glória Diógenes}

Baseado em modos de observação e construção peculiares da elaboração de narrativas em pesquisa, o artigo analisa as condições singulares de uma moradora de rua, brasileira, sem documentos, e com dificuldades de estabelecer vínculos pessoais ou institucionais. Observar e conversar, tendo como inspiração o uso da etnobiografia, guiaram a investigação, feita nos anos de 2015, 2016 e 2017. Seguir a rotina da ocupante de rua tornou-se uma das formas iniciais de verificar como, por meio de sobrevivência tão inóspita, em espaço urbano marcado pela desigualdade, era possível preservar uma regularidade de ações, inventando condições especiais para recriar a "casa" e o "trabalho". A proposta metodológica do artigo, amparada no cruzamento de saberes (sociologia, antropologia e psicanálise), suscita questionamentos sobre como incorporar o tema da singularidade na pesquisa, esgarçando, no limite, as possibilidades da linguagem e da escuta da vida social em suas nuances mais inesperadas.

PALAVRAS-CHAVE: uso da rua, singularidade, etnobiografia, pesquisa, cruzamento de saberes.

A life not to be told: in the paths of singularity - Based on peculiar modes of observation and construction for the elaboration of narrative in research, the article analyzes the singular conditions of a homeless Brazilian woman without any documents for whom the establishment of personal or institutional bonds is difficult. The underlying research, carried out in 2015, 2016, and 2017, was guided by observation and frequent conversations, taking ethnobiography as inspiration. Following the daily routine of this street occupant became one of the initial ways to find out how, through such inhospitable survival in the urban space marked by inequality, it was possible to preserve regularity in actions, inventing special conditions to recreate "house" and "work". The methodological proposal of the article, drawing on the intersection of different knowledge fields (sociology, anthropology, and psychoanalysis), raises questions on how to incorporate the theme of singularity into research, stretching, to the limit, the possibilities of language and listening to social life in its most unexpected nuances.

KEYWORDS: street use, singularity, ethnobiography, research, intersection of knowledge.

BARREIRA, Irlys Alencar F. (irlys.firmo@gmail.com) - Programa de Pós-graduação em Sociologia da Universidade Federal do Ceará (UFC), Brasil.

DIÓGENES, Glória (gloriadiogenes@gmail.com) - Programa de Pós-graduação em Sociologia da Universidade Federal do Ceará (UFC), Brasil. 


\section{INTRODUÇÃO}

Dona Maria. Iniciar assim, pelo seu nome, parece procurar redimir, por meio de pesquisa e escrita acadêmica, o ostracismo de uma moradora de rua. A nomeação, longe de compensar a falta efetiva de sua sonhada carteira de identidade, é também fruto de desafiadora tentativa de acionar um registro de singularidade, comumente esquecido em modelos sociológicos amplos e, como tal, avessos ao que aparenta ser menos relevante.

Não foi pela via da destituição de bens e da falta de reconhecimento que a moradora de rua suscitou uma demanda de investigação. Ao contrário, era sua indumentária típica e o modo de se postar na rua que instigavam a condição de pesquisadoras, interessadas, inicialmente, nas apropriações e nas vivências de segmentos sociais presentes no mundo urbano contemporâneo. Pensávamos nas múltiplas formas de experimentar a espacialidade citadina e nas marcas impostas à vida nas grandes cidades, de modo diferenciado e desigual. ${ }^{1}$

De um lado, as leituras de Simmel (2001 [1903]) nos inspiravam e desafiavam o entendimento a respeito das atuais configurações da vida mental na cidade. De outro, Bourdieu (2001) nos interpelava, em uma via de contramão, a analisar as especificidades dos "miseráveis" brasileiros, diferentes, em alguns aspectos, daqueles presentes no mundo francês. ${ }^{2}$ Michel de Certeau (1994), em sua poética dos passos errantes, evocava a busca de ultrapassagem das linhas previstas na disciplina dos trajetos citadinos, inspirando um olhar sobre os desacertos, o não enquadrado ou as linhas criativas de fuga presentes nas dissonâncias cotidianas.

Paradoxalmente, dona Maria, destituída de bens e documentos, porta um recurso de visibilidade. Sua presença constante em um dos bancos da avenida Beira-Mar - principal via litorânea de passeio e cooper de pedestres, em

1 Segundo informações do portal do Instituto de Pesquisa Econômica Aplicada (IPEA), baseadas em dados de 2015, "o Brasil tem pouco mais de 100 mil pessoas vivendo nas ruas. O Texto para Discussão Estimativa da População em Situação de Rua no Brasil aponta que os grandes municípios abrigavam, naquele ano, a maior parte dessa população. Das 101.854 pessoas em situação de rua, 40,1\% estavam em municípios com mais de 900 mil habitantes e 77,02\% habitavam municípios com mais de 100 mil pessoas. Já nos municípios menores, com até 10 mil habitantes, a porcentagem era bem menor: apenas 6,63\%" (em < http://www.ipea.gov.br/portal/index.php?option=com_content\&vi ew $=$ article\&id $=29303>$, última consulta em outubro de 2019).

2 Os entrevistados de Bourdieu (2001) que representam a "miséria do mundo" são compostos por zeladores de conjuntos habitacionais populares, operários, artesãos, migrantes, comerciantes, pessoas sem-teto, incluindo, nessa condição diferenciada, não só carências econômicas, mas sofrimento oriundo de conflitos de interesses, estando aí presentes a pequena e a grande misérias. Trata-se de pessoas com acessos precários à habitação e bens sociais, em condições variáveis de elaborar demandas individuais ou coletivas no âmbito das políticas públicas. Com raras exceções, os entrevistados da pesquisa feita na França sob a direção de Pierre Bourdieu incluem pessoas em posição de destituição extrema de direitos de cidadania, envolvidas no risco eminente de perderem suas vidas. Esses podem ser identificados como fazendo parte de um segmento dos "miseráveis" brasileiros, no qual enquadramos dona Maria. 
Fortaleza - não passa desapercebida. Podemos dizer que não há como deixar de avistá-la, mesmo que de longe, no vaivém diário que caracteriza a paisagem rítmica desse calçadão litorâneo. ${ }^{3}$

Sua imagem pode ser assim descrita: de cor morena, intensificada pelo sol, estatura baixa, chapéu branco, adornado com galhinhos de planta verde, calça e blusa com predominância de tons avermelhados, cabelo muito preto de quem tem o cuidado de retocar a pintura, unhas grandes e pontiagudas, com uma sujidade depositada, e seus muitos e muitos sacos e sacolas. Os pertences, guardados nesses imensos sacos plásticos, apropriados para guardar lixo, servem para recriar sua "casa". O local escolhido como abrigo pode ser qualquer lugar na beira da praia ou na calçada, onde espalha objetos, galhos de plantas, toalha e utensílios pessoais.

Ela não é uma moradora de rua comum - seja pelo hábito de carregar pesados pertences, desproporcionais ao tamanho de seu corpo, ou por se posicionar na condição de alguém que se mobiliza por conta de um trabalho rotineiro. Diariamente, desloca-se do ponto onde dorme até um dos bancos do calçadão, onde executa uma escrita feita de desenhos enquadrados em retângulos e círculos. O caderno ou papel pautado no qual inscreve seus registros comporta letras contínuas e regulares que não formam palavras, assemelhando-se a frases, com sequências de letras, números, ou imitação de dinheiro, cédulas e moedas).

Sendo uma moradora do espaço da orla, a primeira coisa que nos chamou atenção foi sua aparente altivez, seu modo de estar ali sem estender a mão aos passantes ou assumir qualquer atitude que pudesse provocar piedade e comiseração. ${ }^{4}$ Não éramos as únicas a lhe dirigir o olhar e a buscar entender essa forma de vida diferente da dos demais ocupantes de rua. Uma vez, identificamos a presença de uma jornalista interessada na escrita de alguma reportagem sobre essa emblemática moradora de rua, não enquadrada nas formas usuais de pedintes esfarrapados e expostos em atitudes habituais com as quais se reveste a miséria.

Geralmente, dona Maria senta-se em bancos e ali mesmo faz refeições. Não aceita qualquer caldo ou "vitamina"; algumas vezes recebe trocados de alguns

3 A avenida Beira-Mar, em Fortaleza, foi construída em 1963 e concentra o polo mais significativo de hotéis, flats, restaurantes, áreas de lazer, feirinhas de artesanato e espaços de esporte da cidade. Tal como ressalta Ângela Silva: "A avenida Beira-Mar é hoje um dos importantes pontos turísticos da Cidade. Sendo um dos principais corredores de animação de Fortaleza, oferece belo conjunto visual, formado pelo movimentado calçadão, bares, barracas, coqueiros e os imponentes edifícios da orla. No final da tarde e à noite, transforma-se em ponto de cooper, ciclismo, manifestações culturais, compras na feira de artesanato e passeios informais. Quadras de esportes, pistas de skate, patinação e anfiteatro para shows ao ar livre próximos da Volta da Jurema atraem os transeuntes e proporcionam uma dinâmica na área" (Silva 2006: 55-56).

4 Não são raros os pedintes da orla que usualmente se dirigem aos passantes estendendo a mão e solicitando ajuda financeira para necessidades pessoais imediatas. 
caminhantes que já a reconhecem pela presença constante no local. ${ }^{5}$ Compra merenda de vendedores de seu convívio, preferindo "vitaminas" batidas que, na falta de dentes, facilitam a deglutição. Frequentemente se alonga, sobe e desce o banco, em um tipo de exercício corporal que, pode-se observar, está acostumada a executar. Quando cansada, a moradora da Beira-Mar deita-se sobre os sacos e adormece. Transbordando as fronteiras do mundo urbano que separam a casa da rua, ela recria uma rotina feita de paragens e caminhadas diárias, pontos de chegar, sair ou ficar.

A forma de moradia não é contingencial. Dona Maria vive há mais de 14 anos na rua, sobrevivendo com a ajuda de uma rede de apoio constituída por conhecidos que lhe dão algum dinheiro e dormindo em calçadas ou barracas de praia, as quais lhe servem de abrigo para necessidades cotidianas. Segundo o depoimento de uma estudante universitária que também caminha matinalmente na avenida Beira-Mar, ela morava nas proximidades de uma escola e, à época, foi alcunhada de "Maria Doida". Conhecida nos arredores, dona Maria era, às vezes, apontada como referência negativa para crianças. A tentativa de arranjar-lhe emprego em uma barraca de vendas tinha sido inútil, pois ela afirmava já "ter o seu trabalho". Atualmente, em espaço de maior anonimato, mantém a rotina continuamente recriada de alternância entre "trabalho" e "moradia".

\section{PESQUISANDO POR CAMINHOS INUSITADOS}

Observar, escutar, acompanhar e conversar constituíram recursos metodológicos que guiaram a pesquisa realizada, de modo intermitente, entre os anos de 2015 e 2017. Na impossibilidade de uma investigação com determinações temporais precisas, elegemos a observação diária e as conversas, nem sempre previsíveis, como janelas de entendimento por meio das quais fomos trabalhando as informações, tal como a montagem de um caleidoscópio. Observar a rotina de dona Maria tornou-se uma das formas iniciais de verificar como, por meio de sobrevivência tão inóspita, era possível preservar uma regularidade de ações, recriando condições especiais para "casa" e "trabalho".

Conversar com a personagem exclusiva dessa pesquisa era como flutuar em zonas descontínuas da linguagem. ${ }^{6}$ Ao contrário de uma fala feita para informar, dona Maria parecia não se importar com a pretensão de ser compreendida, apresentando-se como resistente à construção explicativa de marcos de

5 Sobre a discussão que faz referência à rua como lugar de criação e reinvenção, ver Diógenes (2015).

6 Rocha e Eckert (2008: 6) falam sobre os desafios da aproximação ao desconhecido, sendo essa situação ainda mais acirrada no caso de dona Maria, em que “a disposição de escutar o Outro" é tarefa quase nada evidente. Cada fala revela meandros de uma memória que atua na linha da livre associação, em blocos fragmentados de lembranças. 
referência, tal como analisou Barthes (1997: 15) por relação ao uso inusitado da linguagem em determinadas construções literárias. ${ }^{7}$

Perguntas que se costumam fazer em percursos convencionais de pesquisa, quando interessados na montagem de trajetórias, deveriam estar atentas a formas específicas, apontadas por Barthes (1997), de imprecisão da linguagem: "Eu boto que nasci, dizem que nasci, mas eu não sei se foi lá não". ${ }^{8}$ Trata-se de um tipo de fala marcada por furos, vácuos, descontinuidades, deslizes, falhas que, não obstante serem caracterizadas pela imprecisão, apontam também para formas singulares de um dizer. Conversar com dona Maria representou abdicar de um viés sociológico voltado para construir uma história objetiva e representativa sobre pessoas em "situação de rua". A rigor, em investigação que fosse baseada unicamente na organização sistemática de dados fidedignos e dotados de representatividade, dona Maria seria uma informante indesejada, por não apresentar um relato coerente e figurativo dos destituídos de trabalho e moradia.

A investigação sobre a moradora subverteu, assim, os requisitos de uma pesquisa convencional, deixando que a densidade de informações e observações criasse espaços possíveis de interlocução teórica e factual, o que supôs, além disso, a relativização de categorias comumente postas nas pesquisas: sujeito versus objeto, empírico versus teórico, peculiar versus representativo.

Ademais, tornou-se evidente, no processo de investigação, a percepção dos limites do uso de categorias "explicativas" ou dedutivas capazes de fazer entender o "estar na rua" como fruto único de processos de exclusão social. Sentimo-nos convocadas a questionar a "sociedade" como lugar de condensação totalizante, dotado de sentido unívoco, oposto à construção de "sujeitos", buscando linhas de conexão entre a singularidade e as relações que a constituem. ${ }^{9}$ Foi então que a busca de outras experiências de pesquisa incidiu sobre a necessidade de realizar um enfoque de natureza etnobiográfica (Gonçalves, Marques e Cardoso 2012: 10). Tratava-se de seguir pistas, no caso de dona Maria, de sua linguagem e experiência, buscando os nexos possíveis entre singularidade e vida social.

No campo da antropologia, o conceito de etnobiografia veio somar-se ao antigo debate sobre o uso da biografia em pesquisas, problematizando, de modo mais radical, os conceitos abrangentes e substantivados que opõem o

7 O autor utiliza o termo "gozo da linguagem", de inspiração psicanalítica, que se refere ao uso de palavras, fatos ou narrativas peculiares por falantes que não se adequam às estruturas formais de comunicação.

8 "Boto", palavra proveniente do verbo botar usada por dona Maria, implica suposição ou impressão, sem o caráter definitivo da afirmação.

9 Uma reflexão sobre as tensões entre as categorias indivíduo e sociedade no âmbito da sociologia pode ser vista em Barreira (2003). 
individual ao coletivo, ou o sujeito à cultura, e abrindo, assim, espaço para a individualidade. ${ }^{10}$

As narrativas, em sua função de agenciamento, traduziriam experiências do mundo, levando a problematizar

"como o conceito de etnobiografia afeta necessariamente não só o modo como tratamos as histórias que os sujeitos etnografados nos contam, mas também como contamos nossas histórias etnográficas sobre essas histórias e seus personagens-pessoas. Em outras palavras, a etnobiografia implica uma dimensão metanarrativa da etnografia, em que o lugar da agência da própria narrativa etnográfica torna-se objeto etnográfico" (Gonçalves, Marques e Cardoso 2012: 10, grifos no original).

Nessa perspectiva, a realidade não é apreendida apenas a partir de uma representação, incorporando também experiências de mundo. O exercício (Gonçalves, Marques e Cardoso 2012) de "etnografar uma biografia" constituiu uma missão significativa, tendo em vista que verifica, com acuidade, as condições para a realização de um relato, assim como a importância da narrativa na vida cotidiana dos próprios contadores. Essa concepção mais desvinculada do ideal de representatividade permitiria não só relativizar o caráter de "veracidade" como foco da questão, recompondo, com mais vigor, a dimensão de singularidade enfraquecida nos ideais de objetividade, também parte significativa da narrativa científica.

A incursão nessa forma inusitada de fazer pesquisa exigiu o acompanhamento de outras tentativas semelhantes. Biehl (2008: 418), relatando o caso de Catarina Inês Gomes Moraes, que havia sido deixada no Vita, asilo da cidade de Porto Alegre, para morrer, ao se deparar com sua "linguagem labiríntica" e com o escutar intensivo que isso exigia, decidiu empreender um tipo de leitura aberta: "Desde o começo, pensava em Catarina não em termos de doença mental, mas como uma pessoa abandonada que, contra todos os empecilhos e probabilidades, reivindicava uma experiência ao seu próprio modo" (Biehl 2008: 418). Ressalta o autor que Catarina movia as coisas de um registro a outro de um modo que quase sempre escapava à sua compreensão (Biehl 2008: 419). A leitura aberta permitiu, assim, que sentidos outros fossem sendo construídos no percurso da investigação.

10 Para aprofundar a dimensão etnográfica das histórias de vida em torno do uso de relatos e narrativas biográficas, ver o livro de Rocha e Eckert (2013), Etnografia da Duração. Em uma significativa passagem do referido livro, as autoras assinalam: "não se trata de revelar grupos sociais como unidades coesas e homogêneas. O antropólogo vai antes mapeando vozes, gestos, ações, ora uníssonas, ora polifônicas, tanto quanto não-ditos e não-manifestos ou os aspectos não verbais, como expressões corporais, gestuais etc." (Rocha e Eckert 2013: 125). 
Os relatos de Machado Pais (2006) acerca de suas experiências de pesquisa com os "sem-abrigo" em Lisboa também apontam para reflexões bem mais coadunadas com o que fomos observando nos processos de aproximação a dona Maria, suscitando uma recusa do uso do rótulo psiquiátrico de "doença mental". O pesquisador português considera, no caso dos "sem-abrigo", que alguns "comportamentos bizarros poderiam ser considerados 'normais' por parte de quem vive situações de vida verdadeiramente anormais. Há quem os pretenda ver apenas como manifestações de distúrbios mentais: alucinações auditivas e visuais; delírios conspiratórios que se traduzem em temores de perseguição; delírios de sobrenaturalidade" (Pais 2006: 57). Considerando as observações do autor, que se deu a tarefa de investigar os "rastros da solidão", ${ }^{11}$ é possível dizer que, nas classificações generalizantes, perde-se muito da percepção dos que habitam as ruas e dos esquemas mentais que se constroem na articulação entre condições de vida e subjetividade.

A recusa de classificações prévias e generalizantes endereçadas a moradores de rua trouxe também como consequência a ruptura com uma causalidade circular posta na questão sobre a "opção pela rua" como sendo provocada por problemas mentais ou econômicos.

Outros pesquisadores, na busca de superar explicações uniformizadas, percorreram caminhos semelhantes. Frangella (2010), em primorosa etnografia sobre moradores de rua, em São Paulo, destaca a especificidade de suas narrativas, contadas a partir de uma cronologia irregular. Trata-se de depoimentos fragmentados, compostos por uma teia de relações remotas, ainda que apareçam, nesses relatos, a profissão, o trabalho, as interações e os conflitos familiares. Destaca-se, nas falas dos ocupantes de ruas de São Paulo, uma heterogeneidade de circuitos anteriores, com perdas de vínculos familiares, problemas pessoais como alcoolismo e drogadição, distúrbios psicológicos, desilusões amorosas e o desencanto com a sociedade. Esse conjunto alusivo a situações diversificadas permitiu à autora romper com a ideia de homogeneidade frequentemente atribuída aos que moram nas ruas.

A busca de apreensão de diferentes possibilidades de expressão linguística supõe uma outra forma de compreensão e de escuta. Os escritos de Goldman (2014) são elucidativos em torno da tensão veracidade/imaginação no que se refere aos conteúdos narrados nos processos de pesquisa. $\mathrm{O}$ autor, retomando as narrativas da pesquisa de Evans-Pritchard sobre os bruxos Azande, pontua que o antropólogo, em "lugar de dizer 'bruxos, como os Azande os concebem, não podem existir', precisaria sustentar que 'bruxos só podem existir como os Azande os concebem’ - ou como alguém os concebe" (Goldman 2014: 8). É por meio dessa formulação - voltada para entender os lugares específicos de construção de sentido - que Goldman reflete "como funciona a antropologia".

11 Alusão ao título do livro de J. Machado Pais, Nos Rastos da Solidão (Pais 2006). 
Na rota da inspiração antropológica, é possível pensar que, na pesquisa que deu suporte ao presente artigo, o significativo não seria identificar as "verdadeiras causas" da permanência de dona Maria nas ruas, há muitos anos, em contraponto a sua narrativa. Retirar o conteúdo imaginativo de sua "história" seria como atestar a veracidade da existência ou não dos bruxos e dragões na formulação antropológica de Goldman. Não importaria, objetivamente, na mesma sequência, considerar até que ponto "as sabidinhas, ex-patroas e os policiais", segundo os termos que ela utiliza para se referir a pessoas que tiveram papel relevante em sua vida, existem de fato, mas saber como ela os nomeia e lhes confere significado. ${ }^{12}$ Levando-se em conta que essas pessoas às quais dona Maria se refere só adquirem significação a partir do modo como ela as concebe, é importante priorizar as relações que a moradora de rua diz estabelecer com as referidas personagens, tal como é tratado no percurso antropológico:

"Ou seja, não se trata de uma questão de existência ou inexistência, mas do fato que em antropologia lidamos com relações, não com substâncias ou mesmo com ações. Nosso problema, consequentemente, é como incluir os bruxos (ou o que quer que seja) no conjunto das relações que descrevemos e analisamos" (Goldman 2014: 8).

Segundo o mencionado antropólogo - e aqui tomamos de empréstimo esse lúmen de visão -, a comunicação entre a análise da prática científica e aquelas outras consideradas "loucas", "delirantes", "místicas", "só pode ser obtida mediante a introdução de uma assimetria compensatória, destinada a corrigir uma situação assimétrica inicial" (Goldman 2014: 22). Essa assimetria presente na fala descontínua de dona Maria, por meio da qual ela organiza sua história ou seu estar no mundo, suscitou a inspiração antropológica da incorporação de outra lógica, modulando nossos olhares para aquilo que escapa à compreensão usual e parece não fazer sentido imediato nos esquemas analíticos convencionais. Os relatos de dona Maria seriam não só delírios de alguém que "perdeu a razão", mas um modo de se recriar nas bordas de laços sociais. Portanto, nossas constantes escutas nos conduziram a outro plano de pesquisa, guiado pela seguinte questão: de que modo essa narradora, que parecia nada pretender explicar, teceria, com sua imaginação, os fios que constituem seus modos de viver e experimentar a rua?

Foi também na rota de um desencontro entre linguagens e percepções de mundo que Biehl, por meio do esforço incessante de alcançar o que dizia Catarina no asilo Vita, reforçou a perspectiva de que 
“[...] podemos estudar a subjetividade como aquilo que excede e escapa, o que não pode ser fixado por uma norma ou numa forma. A subjetividade está entre formas dadas e a sua temporalidade é a do entrementes. Sintomas e lapsos não estão aí para serem somente interpretados. Trata-se de identificar as suas trajetórias e verificar se estas trajetórias também podem ser indicadores de um novo universo de referência que, potencializado, talvez possa adquirir consistência suficiente e força transformadora" (Biehl 2008: 422).

Assim, trilhamos caminhos já percorridos, embaladas pelo esforço de conhecer os lugares frequentados por dona Maria, os encontros que ela mantinha com o policial e com os vendedores de "vitamina" e caldo, o contato rápido com alguns passantes, os lugares de comer, ficar, dormir e se banhar, enfim, as diferentes formas de interação social que permeavam o cotidiano e suas formas de produção de subjetividade. ${ }^{13}$ Portanto, evitamos que o eixo da observação etnográfica estivesse voltado para as classificações psiquiátricas baseadas em enquadramentos ou categorizações exclusivamente fundadas em supostos generalizantes de exclusão e miséria. E assim escutamos a forma como ela montava sua história.

\section{DONA MARIA POR ELA MESMA}

Ao indagarmos acerca do seu nome completo, ela responde:

"R. - Maria das Graças Mesquita.

P. - Não tem outro nome não?

R. - Tenho, mas o outro eu não boto. Maria das Graças Camelo Mesquita, Camelo era o nome do meu pai e Mesquita o nome da minha mãe, é, ainda tem o outro, o de Oliveira" [conversa com dona Maria, 08/03/ /2016].

$\mathrm{Na}$ fala entrecortada de dona Maria, sua trajetória é assim narrada:

"Tenho 64 anos, nasci em 51, no dia 17 de agosto. O povo diz que eu nasci em Morro Branco, mas eu boto que nasci em Itaipu e Cariré. A gente pode morar em muitos lugares. Eles fizeram tanta putaria com meus documentos, acabaram meu ganho, acabaram o meu documento, acabaram tudo, as minhas coisas eram escondida pra outras. Quem já viu isso, deram minhas

13 Dona Maria diz se banhar com roupa na água do mar e aguardar, ao fim, a hora da secagem, deixando o corpo exposto ao sol. Não conseguimos saber em que momento e de que forma ela tinge os cabelos de preto, tentando disfarçar os fios brancos em torno da sua cabeleira cacheada. 
coisas pra outras escondidas sem eu saber? Os documentos, tanto eu tirava, eles levavam" ${ }^{14}$ [conversa com dona Maria, 08/03/2016].

Dona Maria afirma ter uma irmã e um sobrinho, com os quais não parece manter contato. O sobrinho, de acordo com ela,

“[É] tão ruim que é capaz de tirar uma casa de mim e dar pra outra pessoa. Faz uns 20 anos que eu não tenho trabalho [aqui se refere à função de doméstica], cortaram o meu trabalho, não trabalhei mais não. Que elas não deixaram nem eu trabalhar, nem ir para uma casa, nem me deram teto, nem uma venda, nem nada, fui cortada de tudo de uma vez; agora não sei porque elas fizeram isso, sem eu fazer nada, esse problema é que eu tenho raiva delas" [conversa com dona Maria, 09/10/2017].

Em algumas ocasiões, sua fala atualiza o desejo de um dia ter documentos ou ganhar uma máquina "daquelas do comércio que é cheia de dinheiro". Nesse inventário lacunar de sua trajetória, dona Maria opõe a vida de antes, na qual apresentava uma coerência de propósitos de trabalhadora doméstica considerada até "melhor que as outras" - à de hoje, marcada pela destituição radical de quem "tudo perdeu". As referências às instituições, sobretudo as de controle, e às pessoas são indiscerníveis: "eles que roubaram os documentos e deixaram no cartório" ou "elas as patroas e as empregadas" e a polícia, "que também rouba" [conversa com dona Maria, 06/05/2017).

Dona Maria não representa apenas uma espécie de expressão performática de humilhados e ofendidos. Sua condição singular chama atenção para as possibilidades de articulação entre realidade psíquica e existência social pela via da criação ou reinvenção de si. É nessa perspectiva que se tornam vislumbráveis possíveis contribuições da psicanálise.

\section{O INCONSCIENTE NA PESQUISA}

Percebemos, logo nos primeiros contatos, que não seria possível, em nosso esforço etnográfico, alimentar o fluxo usual de um roteiro de perguntas e respostas. A fala de dona Maria parecia fluir "sozinha”, como se ela já a estivesse exercitando em voz baixa e fôssemos apenas testemunhas de um dimanar de palavras ao vento. Seria um caminho mais previsível identificar uma correlação entre "loucura" e exclusão social ou considerar a personagem pesquisada como exemplo paradigmático de ausência de cidadania. No entanto, percebemos que, diante de alguém que "inventa" o seu lugar na rua, "bota" o seu nome e o 
lugar onde nasceu de um modo próprio e especial, cria um "sistema" particular de escrita, apresenta um jeito peculiar de ser e uma estética que a diferencia dos demais moradores de rua, é imprescindível uma escuta aberta ao inusitado. Algo capaz de acrescer outros pontos de ancoragem a categorias genéricas tais como miséria, exclusão ou segregação. De outro modo, não pretendíamos naturalizar, classificar o que íamos descobrindo acerca dela sem agregar seu delírio e modo de perceber o mundo como partes constituintes de uma linguagem - sua linguagem singular.

Dona Maria, com sua vida e narrativa peculiares, convoca um tipo de registro que foge da captura usual dos depoimentos realizados nas ciências sociais. Portadora de uma fala entrecortada e cheia de deleções, apresenta uma versão singular de sua história, cuja veracidade factual é duvidosa, antes exprimindo um modo original de lidar com a realidade psíquica. $\mathrm{O}$ apelo à singularidade evocou a reflexão sobre as possibilidades de comunicação entre sociologia, antropologia e psicanálise no âmbito da pesquisa, e isso nos desafiava tanto no registro quanto na análise das informações. Chamando atenção para a existência de vivências diferenciadas nas quais emergem as noções de indivíduo e biografia, Velho (1986: 55) ressalta a necessidade de ampliar o espaço de discussão sobre variações e heterogeneidades presentes no mundo social. Desse modo, na percepção do antropólogo, justifica-se uma comunicação mais orgânica entre sociólogos, antropólogos, psicólogos, psicanalistas, filósofos e especialistas em literatura.

Conversar com dona Maria representou incorporar à análise os conceitos de fantasia e delírio, não como aportes da impossibilidade sociológica ou antropológica, mas pensando de que modo o social pode se deixar vislumbrar nas entrelinhas de um dizer faltante, nem sempre lógico ou evidente em uma escuta convencional. A esse respeito, o delírio, na percepção psicanalista de Leader (2013), traz um aporte importante à reflexão. Expressões de delírio não significam o sintoma de uma patologia, mas um modo expressivo e singular de os sujeitos se relacionarem com o inconsciente, usualmente subtraído das investigações na medida em que o enquadram em um nonsense. Dona Maria reitera a condição de alguém que se recria em seu delírio, mesmo em condições adversas, afirmando um estilo ou modo de usar a rua, carregando sua "casa" no corpo, portando uma fala que lhe é própria. Assim, vai recriando sua inscrição no mundo, enunciando "fatos" e narrativas avessos à objetividade.

A recriação de dona Maria tem na estética um espaço expressivo. Ela escreve incansavelmente usando canetas que contrastam matizes azul, verde e vermelho, em cadernos que, ao preencher, guarda entre seus pertences. Os blocos de páginas amassadas pelos ventos constantes que atravessam a orla, registros que perfuraram as páginas pela força contida na mão da escrevinhadora, contêm muitas cédulas de dinheiro desenhadas (figura 1), acrescidas de palavras quase indecifráveis. 
O "caderno" - também especificado por Biehl ao examinar os escritos de Catarina - configura uma espécie de "inconsciente estético" a ser incorporado na observação, acrescentaríamos. Trata-se, como alude Rancière, de "valorizar a potência surda de uma palavra do Outro, irredutível a toda a hermenêutica" (2009: 77). O regime estético nomeado por Rancière (2009) propõe o retorno a um outro freudismo, o qual foge da interpretação de sintomatologias muitas vezes presentes na literatura e na arte e que se lança na "autonomia antirrepresentativa da arte e sua natureza profundamente heteronômica" (Rancière 2009: 76). Dona Maria pode estar, em sua escrita, afirmando um lugar por onde ela "aguenta" ficar, por meio do qual pode "inventar" uma potência não mais "roubada". ${ }^{15}$

Ao indagarmos se ela poderia mostrar as coisas que escreve em seus caderninhos, ela explica de imediato: "As coisas ali não é escrevendo não, é só um sistema, eu ganho mas eles não me dão não". Então, ao perguntar novamente o que escreve, ela reforça que "escreve, mas não sabe para onde vai":

"P. - Aquele sistema que a senhora tá desenhando, D. Maria, a senhora consegue ver pra onde tá indo o dinheiro, é?

R. - Sei não, eu escrevo, mas não sei pra onde vai, eles que sabe, sei de nada não, eles me disseram, né? Eu não sabia não. Maldito ano bissexto, né, que tem essas coisas. Todas as pessoas no ano bissexto é as coisas igual a mim, tem muita gente besta que não sabia, agora todo mundo sabe, até as criança tá ganhando, escreve o bichim, vamos comer um prato de comida, escreve e vão bater lá atrás de um prato de comida" [conversa com dona Maria, 16/09/2017]. ${ }^{16}$

"Maldito ano bissexto", afirma. E emenda: "Agora todo mundo sabe, até as criança tá ganhando" [conversa com dona Maria, 16/09/2017]. A fala e a escrita referem-se a um mundo que ela não sabe explicar e parece estar fora do seu controle. A palavra "sistema" abre a possibilidade de pensar que existe um modo de funcionamento acessível até às crianças, mas que ela não compreende. Seus cadernos podem exprimir a tentativa de dar uma forma a essa incompreensão.

Em uma diretriz de construção de enlaçamento social por meio de obras de arte, Guerra et al. (2006) verificam o estilo do Profeta Gentileza, cuja tentativa de cura psíquica faz de sua obra um objeto estético para ordenar o que, em psicanálise, é denominado excesso narcísico, efeito da condição de criar um mundo próprio, não submetido a regras de enquadramento social. Criticando

15 O uso do verbo “aguentar”, quer dizer, suportar, evoca uma condição agonística de limite.

16 "Bichim" é uma forma reduzida do termo "bichinho", diminutivo usado de forma carinhosa para referir geralmente as crianças ou as pessoas que provocam sentimentos de piedade. 


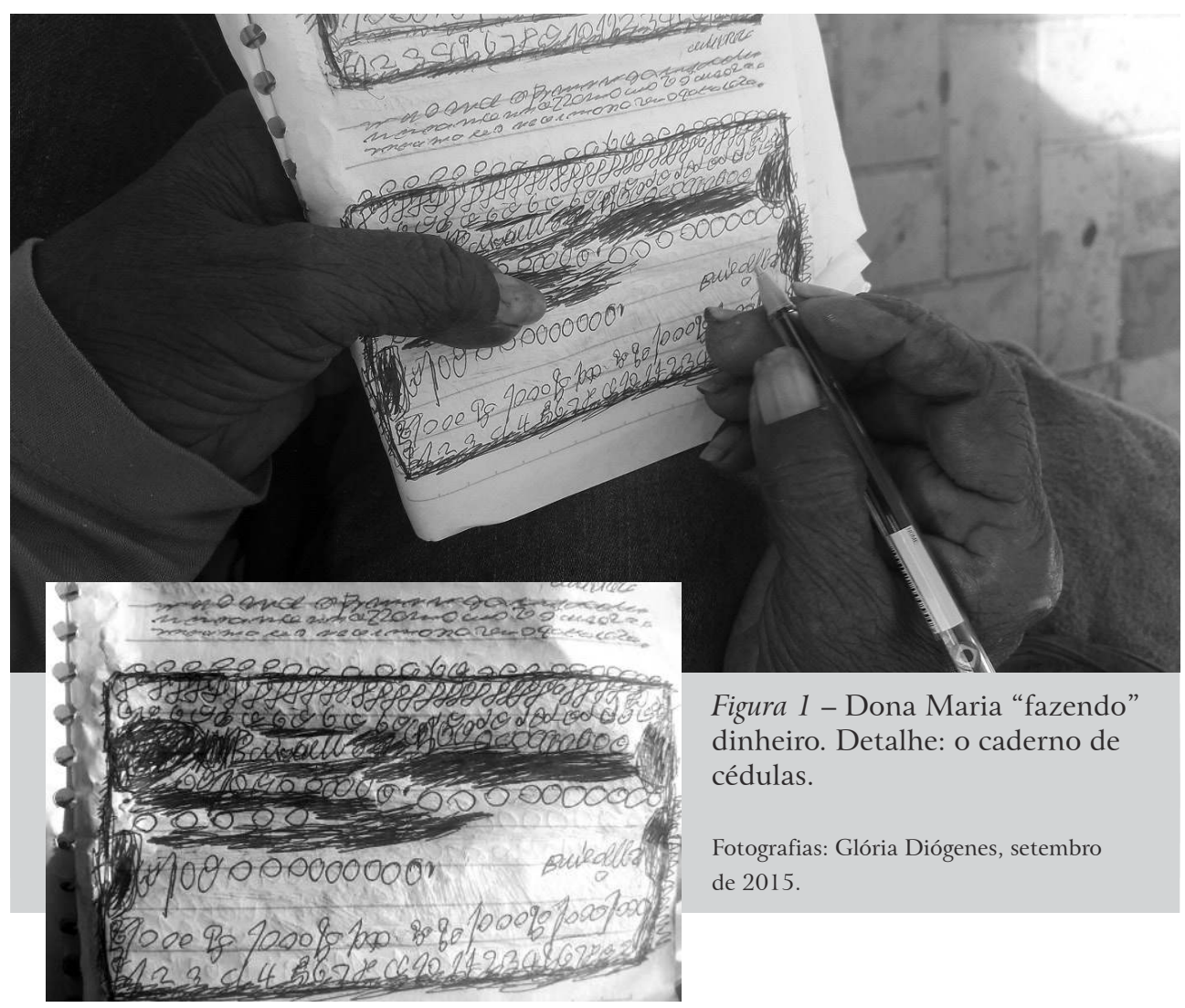

as redes psiquiátricas de assistência, a autora propõe uma perspectiva clínica capaz de acolher a diferença de forma humanizada, fazendo caber o que é classificado como louco nos espaços culturais não adstritos ao enclausuramento. Trata-se de questão já trabalhada por Foucault, quando pensa a loucura como um "halo de desatino que envolve o sujeito de direito; ele é cercado pelo reconhecimento jurídico da irresponsabilidade e da incapacidade, pelo decreto de interdição e pela definição da doença" (Foucault 2012: 134).

No que se refere a dona Maria, sua ruptura com as formas usuais de comunicação carece de reconhecimento jurídico e decreto de interdição. Trata-se de situação contrária à de Arthur Bispo do Rosário, reconhecido artista visual brasileiro que pertenceu à Marinha, tendo sido, aos 29 anos, diagnosticado de esquizofrenia paranoide, o que o levou a viver 50 anos dentro da colônia psiquiátrica Juliano Moreira. ${ }^{17}$ Antes mesmo da reclusão na colônia, ainda

17 "Em 1925, muda-se para o Rio de Janeiro, onde trabalha na Marinha Brasileira e na companhia de eletricidade Light. Em 1938, após um delírio místico, apresenta-se a um mosteiro que o envia para o Hospital dos Alienados na Praia Vermelha. Diagnosticado como esquizofrênico-paranoico, [continua] 
quando marinheiro, Bispo morava nos navios em que trabalhava, como se houvesse conhecido o cárcere e a reclusão em alto-mar (Dantas 2009: 20). Dona Maria segue "fora de casa", alheia às instituições, sem documentos que a identifiquem.

Não há registros de passagens de dona Maria por instituições, até porque o fato de não apresentar demonstrações públicas de desorganização mental a torna inofensiva à vista do controle das regras sociais. ${ }^{18}$ Algumas vezes, vimos dona Maria manifestar revolta. Diante de pessoas fazendo cooper e pronunciando frases de animação, em um ritual próprio de corridas, ela reclamava elevando a voz, que, para correr, "não era preciso gritar", "não era preciso fazer aquela putaria". Outra vez a encontramos queixando-se de que umas pessoas passavam "dizendo coisas" a ela. Ela, que "não mexia com ninguém", também não gostava que ninguém "mexesse" com ela. ${ }^{19}$ Outra vez queixou-se de que a tinham expulsado de uma barraca muito cedo, quando ainda dormia. Diziam que ela era "ladrona", mas "os ladrões eram mesmo todos os donos de barraca" [conversa com dona Maria, 06/04/2016]. Mais recentemente, nós a encontramos de pé, em cima do banco da avenida, discorrendo raivosamente contra passantes que supostamente a insultaram. Em sua fala, referia-se a seu trabalho doméstico de preparar café para as patroas, as quais nem a deixavam disfrutar da comida que ela própria fazia para os membros da família.

Os mecanismos psíquicos utilizados por dona Maria apontam a formulação criativa de outras linguagens que se aproximam do delírio, acompanhadas de comportamentos que desafiam as instituições pelo lado socialmente designado como loucura. Se alguns segmentos de rua constituem a população potencial de presídios, margeando a transgressão enquadrável no âmbito jurídico, dona Maria porta a situação factível de uma classificação psiquiátrica, o que pode a excluir da condição direta da repressão, mas a expõe a outras vulnerabilidades.

[continuação] é internado na Colônia Juliano Moreira, no bairro de Jacarepaguá, no Rio de Janeiro. Entre 1940 e 1960, alterna os momentos no hospício e períodos em que exerce alguns ofícios em residências cariocas. No começo da década de 1960, trabalha na Clínica Pediátrica Amiu, onde vive em um quartinho no sótão. Ali, inicia seus trabalhos, realizando com materiais rudimentares diversas miniaturas, como de navios de guerra ou automóveis, e vários bordados. Em 1964, regressa à colônia, onde permanece até a sua morte. Cria por volta de 1000 peças com objetos do cotidiano, como roupas e lençóis bordados. Sua produção está reunida no Museu Bispo do Rosário, denominado anteriormente Museu Nise da Silveira, localizado na antiga Colônia Juliano Moreira" (do website "Escritório de Arte. com", em < https://www.escritoriodear te.com/artista/arthur-bispo-do-rosario > (última consulta em outubro de 2019).

18 Foucault (2002) menciona em seus trabalhos que personagens consideradas estranhas ou hilárias que habitavam as ruas em momentos históricos passados foram posteriormente classificadas como "loucas", sob o princípio dos dispositivos institucionais.

19 A expressão "mexer com" é usada popularmente no nordeste do Brasil para referir-se a um tipo de provocação verbal ou física. 
PELAS JANELAS DA VIDA SOCIAL

O recorte analítico baseado na singularidade supôs abdicar, na pesquisa, do pressuposto de generalidade, sem desconsiderar que a precariedade em que vive dona Maria associa-se aos requisitos provenientes de uma situação social. Sua condição de "doméstica" exprime uma forma de ser de trabalhadoras cearenses, migrantes do campo para a cidade e que encontram em casas de famílias abastadas, "as patroas", a condição quase exclusiva de sobrevivência.

É importante também considerar que a linguagem de dona Maria é permeada de marcas sociais fundantes em representações culturais, sendo a casa e o trabalho os elementos de recriação de si e a busca de se situar no mundo urbano. Os referenciais de sua prática cotidiana - casa e trabalho - dão suporte à reconstituição de um tempo e um espaço. Assim, enuncia no momento em que a saudamos e perguntamos se está tudo bem: "Tudo bem não, eu não tenho casa" [conversa com dona Maria, 06/04/2016]. Sem lugar fixo, a "casa" é carregada no corpo, podendo se recriar em vários espaços. ${ }^{20} \mathrm{O}$ "trabalho de escrita" permite construir a rotina do tempo, materializando-se em uma forma. Sem instituir uma obra de arte como faz o profeta Gentileza (Guerra et al. 2006), dona Maria cria uma cenografia de passos errantes, um estilo próprio, tal como um quadro posto na cena anônima da vida urbana (figura 2).

Essa condição de recriação das rotinas de casa e trabalho foi também tratada por José de Souza Martins (2015), incluindo exemplos de moradores de

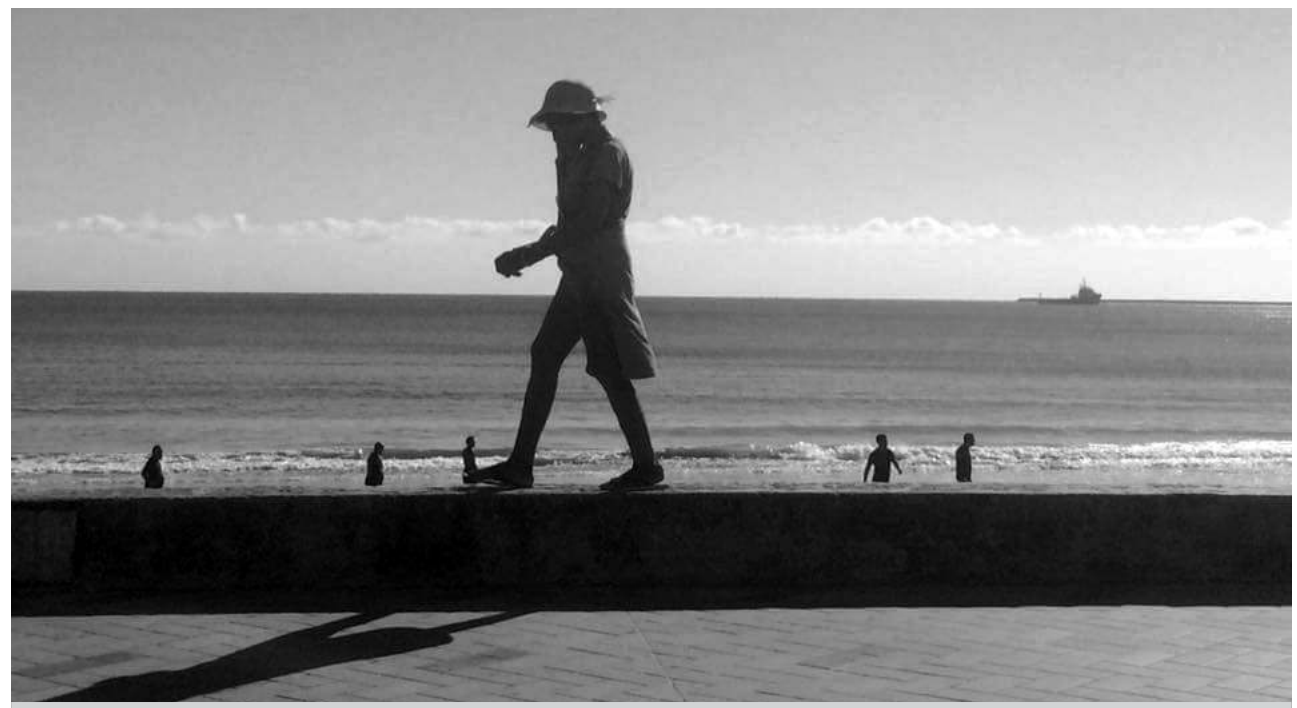

Figura 2 - Os passos de dona Maria. Fotografia: Glória Diógenes, agosto de 2016.

20 Acerca da condição do uso do corpo como "casa”, ver a tese de Lídia Pimentel, Vidas nas Ruas: Corpos em Percurso no Cotidiano da Cidade (Pimentel 2005). 
rua que constroem cenários espaciais e reproduzem as condições de casa e trabalho. Junto ao tema da destituição, que não se revela de forma absoluta, evidenciam-se as possibilidades de invenção da vida no espaço urbano.

A recomposição inventiva estende-se também à linguagem. O termo "putaria", frequentemente repetido por dona Maria, constitui a palavra que designa o "que fizeram com ela" -a "traição da patroa", das outras domésticas que "tiraram seu lugar", até dos parentes que não a acolheram. ${ }^{21}$ Informa, ainda, que, na casa onde trabalhava, "a patroa se bateu com a empregada, foi a maior putaria; por causa da putaria das outras fui jogada para fora e ninguém arrumou nada para mim" [conversa com dona Maria, 07/05/2016, grifo nosso]. O palavrão ou insulto em questão opera como um significante que sintetiza uma série de acontecimentos, envolvendo pessoas e instituições, traduzindo a ideia de que tudo é a mesma coisa ou tem a mesma origem. O mundo é feito de tramas que opõem perdedores a ganhadores. "Eu vim pra rua por perversidade, por ruindade", repete em uma de suas falas [conversa com dona Maria, 07/05/2016].

O discurso entrecortado de dona Maria é também permeado por referências morais: ${ }^{22}$

"Eu sou direita, eles é que não prestam. Na rua eu tenho 'desconhecidos', mas não são mais meus amigos, não. Amigo assim de conversar tenho não, chegam nem perto de mim, eu sou direita, não sou ladrona, não sou assassina, não gosto de pessoal que faz as coisas. O povo tá é fazendo mais ruindade" [conversa com dona Maria, 07/05/2016].

Há também uma personagem chamada Roberto Bombeiro, mencionada por ela com muita frequência.

"Ele prende toda mulher que ele namora. Ele é o homem grande do Brasil; é bom, é conversador, ele trabalha também na Universidade. Ele anda por todo Nordeste, ele é dono do olhar se tá suja as coisas. Ele entra assim

21 Não é possível desconsiderar a condição de gênero e todas as situações implicadas na vida de mulheres que moram nas ruas. Um estudo realizado em São Paulo sobre essa questão mostrou que especialmente as mulheres que pernoitam na rua sofrem violência física de pessoas ou grupos intolerantes com a situação vivida por elas. As práticas de rejeição são também acionadas por policiais, indivíduos contratados por comerciantes ou moradores que se sentem ameaçados em seu comércio e domicílio ou incomodados por cenários que desabonam a cidade. Para um aprofundamento da temática, ver Biscotto et al. (2016).

22 A situação de estigma é também explorada em pesquisa que analisa tipificações oscilando entre a violência e repulsa física, sendo as palavras de rejeição louca, suja, perigosa e coitadinha as mais comuns. Em seus depoimentos e falas em tom alto dirigidas a supostos agressores dona Maria está sempre a afirmar sua condição de mulher direita que nunca roubou, afirmando também a diferença em relação a outras. Ver, a esse respeito, Mattos e Ferreira (2004). 
numa casa, ele é do Governo. O pessoal de Fortaleza são maluco. Como é que o homem vive no apartamento desses [referindo-se aos prédios da avenida Beira-Mar], com todos os preparativos?

P. - A senhora não tem nem certidão de nascimento?

R. - Tá lá no cartório, tem não. Eu comecei tirar, mas num tirei não, eles rouba também meus documentos tudo, registro eles roubam também, o Roberto sabe, ele sabe onde ele tá e o roubo foi com ele, o pessoal dele, mas não é ele não, é o pessoal que é louco, eu não faço isso, roubar o documento das pessoas.

P. - Quem é que rouba?

R. - É tudim da cidade, tudim das casas de família, tem casa de família que manda as empregadas vir roubar, na mesma casa que eu trabalhei, mandaram os empregado dela me roubar aqui, eu tava dormindo, levaram todas as minhas coisas e um trocadinho que eu tinha, mesmo assim. Tudim da cidade roubaram os documentos" [conversa com dona Maria, 07/05/2016, grifos nossos $].{ }^{23}$

As informações de dona Maria seguem o ritmo aleatório de sua imaginação, isto é, a capacidade de construir um mundo próprio que funciona segundo uma lógica singular explicativa. Os documentos existem e não existem ao mesmo tempo - "tá lá no cartório, tem não, eu comecei a tirar..." Tudo se passa como se as fronteiras entre o mundo real e suas percepções estivessem borradas. As incompreensões acerca do funcionamento de instituições e regras sociais transformam-se em narrativas compostas por atores que personificam atitudes propositais e premeditadas que confirmam sua destituição de reconhecimento social. Nessa formulação, dona Maria lança mão de sentidos por meio dos quais interpreta o mundo, mesclando imaginário e realidade.

No entrelaçamento entre imaginação e realidade, é importante, mais uma vez, lembrar que Bispo do Rosário se recolhia em sua cela, na colônia, para se preparar para uma espécie de "transformação" (Dantas 2009: 36), tal qual pronunciava. "A porta do quarto-forte fechava e ele ficava ali, muitas vezes durante meses, sem falar, sem receber a luz do sol, jejuando num suplício imposto pelo Todo Poderoso e pela Virgem" (Dantas 2009: 36). Como ressalva a citada autora, Bispo se transformava "na solidão de sua caverna" (Dantas 2009: 38). O isolamento lhe possibilitava bordar incansavelmente mantos e estandartes e, assim, preparar suas transformações. O que o mantinha entre paredes fechadas? Que dragão espreitava sua passagem?

Tim Ingold (2012: 19), por meio de um texto intitulado "Caminhando com dragões: em direção ao lado selvagem”, relata uma história datada, segundo o autor, possivelmente do ano 549 a. C., contada no livro $A$ Vida de São Benedito 
de Núrsia, acerca de um monge que alega com ardor ter se deparado com um dragão. Mesmo aramado pelas paredes do mosteiro, o monge é acometido por visões de um dragão a persegui-lo sem trégua. Até que um dia São Benedito, já fatigado de suas lamúrias, dá consentimento para que o monge possa afastar-se. Conta a lenda que, logo que atravessa as portas, o monge descobre seu caminho bloqueado pelo horrendo dragão e regressa ao mosteiro, visivelmente terrificado. Na tentativa de também atestar a existência de tão extraordinário ser, alguns monges seguem o mesmo trajeto e retornam sem nada avistar. Há, porém, evidências de sua aparição. O corpo do monge que dele esteve próximo tremia dos pés à cabeça e tinha as vestes ensopadas. Ali, apenas ali, o dragão existia. Como diz Ingold, "o dragão não era a causa objetiva do medo, ele era a própria forma do medo" (Ingold 2012: 18). Entre o mundo "fechado" da instituição e a vida "aberta" da natureza, havia um dragão burlando a passagem. ${ }^{24}$

Esses eram os caminhos bloqueados por meio dos quais o monge personificava o lado de dentro das instituições. Entre a "solidão da caverna" de Bispo e a condição de trânsito entre espaços de dona Maria, é possível encontrar semelhanças emblemáticas. $\mathrm{O}$ dragão que parece vigiar a passagem entre $\mathrm{o}$ mundo de fora e o mundo fechado das instituições pode receber nomes diversos:

"As patroas e as empregadas. Também, ela foi criada com elas, nessa arrumação, aí espalhou em todo mundo, é todo mundo. Não me dão comida, não me dão nada, eles dão comida a todo mundo que tá na rua, mas a mim não me dá. [...] Eles fizeram tanta putaria agora com meus documentos, tanta putaria, acabaram meu ganho, acabaram o meu documento, acabaram tudo, as minhas coisas deram escondida pra outras, quem já viu isso, deram minhas coisas pra outras escondida sem eu. [...] A polícia é contra mim, eu não gosto não, até elas me roubam, eles não gostam de mim não, porque ele é jogado com a putaria a polícia, aqui é tudo arrodeada de putaria, muié da putaria. Eles gostam, a polícia, ele bole comigo, bole assim, xingando, né eles não, mandam. Quando eu tou com raiva eu digo, que às vezes eu brigo pra eles verem mesmo, eu brigo mesmo pela ruindade com a minha vida, tem dias que eu tou com raiva, anoitecer na rua não ter pra onde ir, não tem tem onde entra, né? Ave Maria. É ruim demais, eu nasci e me criei em casa, eu não nasci em rua não, faz vinte anos que eu saí, não tinha nada, né? Por isso que eu tou aqui, alguma coisa de negócio dos pais, né? Eu não sabia, né? Não disseram pra gente. Era como a gente fosse pobre. Elas aproveitaram, 
eu não, ainda tou no mesmo liseira que eu era pobre, tomaram foi tudim pra elas, eu não sei de nada, passaram tudo pra quem não conheço, as sabidinhas" [conversa com dona Maria, 14/07/2015].

Observa-se que "as patroas", as "empregadas sabidinhas", a "polícia” ("tudim"), no imaginário de dona Maria, roubaram algo que lhe pertence. Por isso, quando está com raiva, ela enuncia: "Eu digo que às vezes eu brigo pra eles verem mesmo, eu brigo mesmo pela ruindade com a minha vida". Os "dragões" de dona Maria (empregadas e patroas), há 20 anos, tomaram o que era dela, ou, de acordo com suas palavras, "passaram tudo pra quem não conheço". As "sabidinhas" provocam em dona Maria a percepção de tudo aquilo que falta: "Era como a gente fosse pobre. Elas aproveitaram, eu não, ainda tou na mesma liseira que eu era pobre, tomaram foi tudim" [conversa com dona Maria, 14/07/2015].

O dinheiro, como aquilo que falta, ganha as páginas de seu caderno, numa simulação de que possa ser devolvido o "tudim" que ela diz que perdeu. Tendo ou não sido roubada, sendo desfalcada ou não de seus pertences, do que pode ter conquistado ao longo das décadas em que afirma ter trabalhado em "casa de família", dona Maria, por mais de dois anos de conversa, assegura o mesmo fato: "Não tenho casa, tomaram tudim de mim" [conversa com dona Maria, 14/07/2015].

Os cadernos de Artaud (Lage 2009), os bordados de Bispo (Dantas 2009), os escritos do profeta Gentileza, espalhando "frases de amor pelas pilastras cinzas do rio" (Santos 2017), e os cadernos de dona Maria certamente possibilitam a tentativa de agenciamento de personagens no mundo, convocando um tipo de "partilha do sensível", ${ }^{25}$ segundo expressão de Rancière (2005: 15) referindo-se à existência de um "comum" partilhado em diferentes invenções e estéticas do delírio.

\section{ATANDO FIOS SOLTOS...}

Os depoimentos têm sido bastante utilizados em sociologia como modo de recuperar não só trajetórias individuais, mas contextos históricos especiais, incluindo profissões, ideologias, processos de mudança, dentre outros. Foram considerados úteis para registrar o que não havia, ainda, sido objetivado em documento. Contrapondo-se aos métodos quantitativos, visavam preservar a memória, muito embora recebessem críticas, pois, supostamente, tais depoimentos poderiam ser considerados “infiéis" porque contaminados pela psique individual (Queiroz 1988). 
Dona Maria rompe com a linguagem usual dos depoimentos em pesquisa na área de ciências sociais. Sua fala é entrecortada e cheia de elipses; apresenta uma narrativa cuja veracidade é duvidosa, antes exprimindo um imaginário, conforme foi exposto ao longo do artigo. Próxima de uma representação literária, dona Maria parodia uma espécie de Macabéa, personagem de Clarice Lispector (1981 [1977]), singularizando a complexidade de humilhados e ofendidos que povoam as ruas da cidade. ${ }^{26}$ Uma less entre os demais, entre os "loucos da rua" que não se enquadram nas categorias genéricas que cercam as classificações. Conceder-lhe um lugar de fala e escuta é, de algum modo, construir visibilidade para o seu dizer entrecortado, no qual a fantasia reina sobre espaços inóspitos da vida urbana.

O recurso à singularidade mostrou-se, portanto, revelador de que os avessos ou inesperados indicam formas criativas e práticas que parecem transbordar uma ideia de ordem, presente não só na vida social, mas em muitas pesquisas. Trata-se de questão já trabalhada por Elias (1995) quando, na busca de explicar a genialidade de Mozart, ${ }^{27}$ lança mão das pulsões criativas, no sentido freudiano, para dar conta da produção musical em contexto pouco favorável. No caso de Mozart, a genialidade concedia visibilidade ao fazer musical criativo, ainda que descompassado no tempo.

Registrar a singularidade representou, na pesquisa tratada neste artigo, fazer emergir na sociologia e na antropologia sua capacidade de acolher o individual. Não só escrever sobre a diferença que se apresenta de imediato, mas refletir sobre a opacidade das formas mais escondidas e complexas do viver. Dona Maria apresenta a história que não se conta.

Diariamente, observamos dona Maria com a curiosidade de mais uma vez mirar a sobrevivente às intempéries do espaço e do tempo como quem espera algum dia não mais a ver. Perguntamo-nos: ela ainda está viva? Ao percebermos sua constante exposição ao sol em uma cidade onde pouco chove e cuja temperatura média é de $30^{\circ} \mathrm{C}$, sujeitada ao relento das temporárias chuvas, indagamos: como pode dona Maria estar sempre na Beira-Mar (pelo menos ao longo dos últimos dois anos) sem reclamar de nenhuma doença? ${ }^{28}$

As "astúcias" de dona Maria, como cria táticas para driblar sol, chuva, fome, frio, vento, necessidades fisiológicas, dentre outras, não seriam uma espécie de arte de "praticar cidade" (De Certeau 1994)? Ou seja, a arte, mesmo que

26 Macabéa é a personagem principal do romance $A$ Hora da Estrela, escrito por Clarice Lispector (1981 [1977]). O romance fala sobre a vida da datilógrafa alagoana Macabéa, que se muda para o Rio de Janeiro e tem sua rotina contada por um escritor fictício denominado Rodrigo S. M.

27 Uma reflexão sistemática sobre a obra de Elias Sociologia de Um Gênio pode ser vista em Barreira (1997).

28 Vale ressaltar que as epidemias de gripe, de Zika e Chikunguny têm concentrado no Ceará 59\% dos casos de incidência dessas doenças no Brasil (<https://gl.globo.com/ceara/noticia/ceara-ja-tem -mais-de-927-mil-casos-de-chikungunya-confirmados-1 10 -pessoas-morreram.ghtml >). 
trágica, de estar ali e resistir, de "inventar" dinheiro, de compor um corpo que encontra sua própria "casa" (figura 3). O ato de rabiscar, afora qualquer sentido do comunicar ou explicar, possibilita o movimento de um tipo peculiar de nomadismo. ${ }^{29}$ É nesse sentido que o trajeto de rua é visto por Frangella ${ }^{30}$ (2010) como indutor de uma outra subjetividade, evidentemente sofrida e desafiadora, emprestando singularidade a esse segmento de pessoas que habitam as ruas.

A proposta metodológica deste artigo se lança no cruzamento de saberes (sociologia, antropologia e psicanálise) e suscita questionamentos sobre como incorporar o tema da singularidade na pesquisa, esgarçando, no limite, as possibilidades de escuta da vida social em seus matizes mais inusitados. Dentre os aspectos relacionados à singularidade, enfatizamos: a criação como forma de se inserir no mundo, com matérias e linguagens pouco reconhecidas; a comunicação entre áreas do conhecimento, suas possibilidades de interpretação de situações inusitadas; e a forma como a vida social se deixa ver por vias não convencionais.

O sentido de singularidade inspirou-se na psicanálise quando retoma a história de cada um atravessando

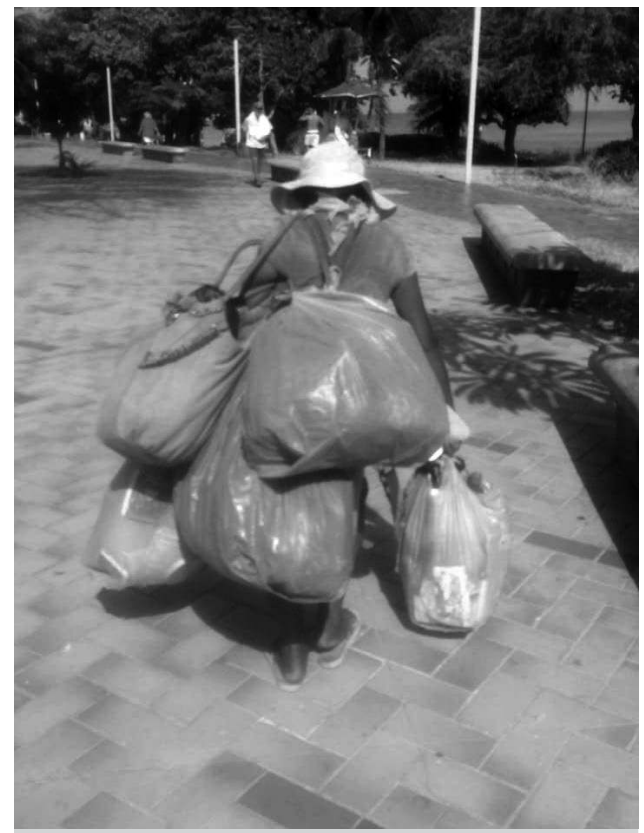

Figura 3 - O corpo e os pertences. Fotografia: Glória Diógenes, dezembro de 2017.

uma estrutura de disposições, mistura de afetos e sentimentos que, de várias formas, escapam às classificações ou nomeações com as quais tanto a ciência quanto as instituições procuram lidar. Por outro lado, a antropologia, na busca de observar para além das recorrências, encontra nas singularidades as marcas inscritas pela vida social que se escondem nos bastidores das cenas menos evidentes. Nosso intuito nesse escrito foi o de tentar avivar essas várias marcas, entendendo que, nesse borrar de fronteiras disciplinares, certas linhas de

29 Como se referem Deleuze e Guattari (1997: 51), o nômade, "embora siga pistas costumeiras, não tem a função do caminho sedentário, os pontos para ele são alternância dos trajetos". Isso significa dizer que, mesmo Bispo, "na solidão de sua caverna", e Catarina, por tantos anos isolada no Vita, são nômades, na acepção de Deleuze e Guattari, porque são desterritorializados por excelência, sendo eles mesmos os vetores de desterritorialização (1997: 53).

30 A dimensão de subjetividade abordada por Frangella (2010) baseia-se em Deuleze quando analisa as possibilidades de constituição de sujeitos construídos à margem de saberes instituídos. 
um fino pincel podem instituir traços. Nesse desenho, falas inaudíveis, modos inusitados de viver e tudo aquilo que definimos como inapreensível podem ajudar a reconhecer modos de ser e viver muito diferentes, passíveis de olhares e escutas da vida social.

Escolhemos uma cena semelhante a um quadro para finalizar este artigo.

"Avistamos de longe dona Maria no mesmo banco, no mesmo local. A diferença é que ela estava em pé no banco de cimento, com lençol, feito um manto amarrado no pescoço, descendo por todo o corpo (parecia o do Bispo do Rosário). Havia ao lado dela apenas um saco e uma sacola (faltou uma câmara para registrar essa cena). Atrás de seu corpo repousavam galhos de uma planta que ela disse que dava sorte. Havia uma parte dessa planta no cabelo (nesse momento, sem chapéu). Assim que foi vista, foi logo dizendo: 'Tô com raiva, roubaram minhas coisas'. Não sabia dizer se tinha sido enquanto dormia ou se haviam carregado daquele banco. À medida que fomos conversando, ela foi se acalmando. Ao indagar por qual razão ela achava que roubaram suas coisas, ela disse: 'Pra saber o que tem dentro'” [diário de campo de 08/04/2016].

Ao fim dessas linhas, ficamos nos indagando: até que ponto nós, pesquisadoras, também "roubamos" suas palavras em busca de uma tradução sociológica ou antropológica do seu modo de falar e estar no mundo? E se nos perguntássemos qual a razão de tudo isso, poderíamos simplesmente responder, utilizando suas palavras: "Pra saber o que tem dentro". Ou melhor, para tentar abrir fronteiras do saber acadêmico e ampliar as difíceis possibilidades de escuta no âmbito nas ciências sociais. 


\section{BIBLIOGRAFIA}

BARREIRA, Irlys F., 1997, "Mozart: Sociologia de Um Gênio, de Norbert Elias", Revista Brasileira de Ciências Sociais, 1: 41-45.

BARREIRA, Irlys F., 2003, "O lugar do indivíduo na sociologia: sob o prisma da liberdade e dos constrangimentos sociais", Revista de Ciências Sociais, 34 (2): 51-64.

BARTHES, Roland, 1997, Aula. São Paulo, Cultrix.

BIEHL, João, 2008, "Antropologia do devir: psicofármacos - abandono social - desejo", Revista de Antropologia, 51 (2): 413-449.

BISCOTTO, Priscilla Ribeiro, et al., 2016, "Compreensão da vivência de mulheres em situação de rua”, Revista da Escola de Enfermagem da USP, 50 (5): 749-755.

BOURdieU, Pierre, 2001, A Miséria do Mundo. Petrópolis, Vozes.

DANTAS, Marta, 2009, Arthur Bispo do Rosário: A Poética do Delírio. São Paulo, Unesp.

DE CERTEAU, Michel, 1994, A Invenção do Cotidiano 1: Artes de Fazer. Petrópolis, RJ, Vozes.

DELEUZE, Gilles, e Félix GUATTARI, 1997, Mil Platôs: Capitalismo e Esquizofrenia. São Paulo, Editora 34.

DIÓGENES, Glória, 2015, “Artes e intervenções urbanas entre esferas materiais e digitais: tensões legal-ilegal”, Análise Social, L (217): 682-707.

ELIAS, Norbert, 1995, Mozart: Sociologia de Um Gênio. Rio de Janeiro, Jorge Zahar Editor.

FOUCAUlT, Michel, 2002, História da Loucura. São Paulo, Perspectiva.

FOUCAUlT, Michel, 2012, Os Anormais: Curso no Collége de France (1974-1975). São Paulo, Martins Fontes.

FRANGElla, Simone Miziara, 2010, Corpos Urbanos Errantes: Uma Etnografia da Corporalidade de Moradores de Rua em São Paulo. São Paulo, Annablume/FAPESP.

GOLDMAN, Marcio, 2014, "Da existência dos bruxos (ou como funciona a antropologia)", Revista de Antropologia da UFSCAR, 6 (1): 7-24.

GONÇALVES, Marco A., Roberto MARQUES, e Vânia Z. CARDOSO, 2012, "Introdução”, em M.A. Gonçalves, R. Marques e V.Z. Cardoso (orgs.), Etnobiografia: Subjetivação e Etnografia. Rio de Janeiro, 7 Letras, 9-17.

GUERRA, Andréa Maris Campos, et al., 2006, "A função da obra na estabilização psicótica: análise do caso do profeta Gentileza", Interações, 11 (21): 29-56.

INGOLD, Tim, 2012, “Caminhando com dragões: em direção ao lado selvagem”, em C.A. Steil, e I.C. M. Carvalho (orgs.), Cultura, Percepção e Ambiente. São Paulo, Terceiro Nome/ Capes, 15-29.

LAGE, André Silveira, 2009, "Os cadernos de Antonin Artaud: escritura, desenho e teatro", Sala Preta, 9: 31 1-316, disponível em < https://www.revistas.usp.br/salapreta/article/vie w/57414/60396 > (última consulta em outubro de 2019).

LEADER, Darian, 2013, O Que é Loucura? Delírio e Sanidade na Vida Cotidiana. Rio de Janeiro, Jorge Zahar Editor.

LISPECTOR, Clarice, 1981 [1977], A Hora da Estrela. Rio de Janeiro, José Olympio.

MARTINS, José de Souza, 2015, "A reinvenção da cidade na selva", apresentado no 39. ${ }^{\circ}$ Encontro Anual da Anpocs, grupo de trabalho "De cidades à cidade no Brasil: tempos e/ou espaços", Caxambu.

MATTOS, Ricardo Mendes, e Ricardo Franklin FERREIRA, 2004, "Quem vocês pensam que (elas) são?: representações sobre as pessoas em situação de rua”, Psicologia \& Sociedade, $16(2): 47-58$. 
PAIS, José Machado, 2006, Nos Rastos da Solidão: Deambulações Sociológicas. Porto, Âmbar. PIMENTEL, Lídia Valesca Bonfim, 2005, Vidas nas Ruas: Corpos em Percurso no Cotidiano da Cidade. Fortaleza, Universidade Federal do Ceará, tese de doutorado em Sociologia. QUEIROZ, Maria Isaura Pereira de, 1988, "Relatos orais: do indizível ao dizível”, em O. R. M. Von Simson (org.), Experimentos com Histórias de Vida (Itália-Brasil). São Paulo, Vértice, 14-43.

RANCIÈre, Jacques, 2005, A Partilha do Sensível. São Paulo, Editora 34.

RANCIÈRE, Jacques, 2009, O Inconsciente Estético. São Paulo, Editora 34.

ROCHA, Ana Luiza Carvalho da, e Cornélia ECKERT, 2008, "Etnografia: saberes e práticas", Iluminuras, 9 (21), DOI: 10.22456/1984-1 191.9301, disponível em < https://seer.ufrgs.b r/iluminuras/article/download/9301/5371 > (última consulta em outubro de 2019).

ROCHA, Ana Luiza Carvalho da, e Cornélia ECKERT, 2013, Etnografia da Duração: Antropologia das Memórias Coletivas nas Coleções Etnográficas. Porto Alegre, Marcavisual.

SANTOS, Bruna Moura, 2017, "Profeta urbano: Gentileza espalhou frases de amor pelas pilastras cinzas do Rio”, jornal O Globo, 23 de março, disponível em < https://acervo.ogl obo.globo.com/em-destaque/profeta-urbano-gentileza-espalhou-frases-de-amor-pelas-pil astras-cinzas-do-rio-21 $110749>$ (última consulta em outubro de 2019).

SIlvA, Ângela Maria Falcão da, 2006, A Cidade e o Mar: As Práticas Marítimas Modernas e a Construção do Espaço da Praia do Futuro (Fortaleza-Ce-Brasil), Fortaleza, Universidade Federal do Ceará, dissertação de mestrado em Geografia.

SIMMEL, Georg, 2001 [1903], "A Metrópole e a vida do espírito”, em C. Fortuna (org.), Cidade, Cultura e Globalização. Oeiras, Celta, 31-43.

VELHO, Gilberto, 1986, Subjetividade e Experiência: Uma Experiência de Geração. Rio de Janeiro, Jorge Zahar Editor. 